\title{
Nonomuraea soli sp. nov., an actinomycete isolated from soil
}

Correspondence
Yi Jiang
jiangyikm@hotmail.com

\author{
Yan-Ru Cao, ${ }^{1,2}$ Rong-Xian Jin, ${ }^{1}$ Yi Jiang, ${ }^{1}$ Wen-Xiang $\mathrm{He}^{2}$ \\ and Cheng-Lin Jiang ${ }^{1}$
}

\author{
${ }^{1}$ Key Laboratory of Microbial Diversity in Southwest China, Ministry of Education and Laboratory for \\ Conservation and Utilization of Bio-Resources, Yunnan Institute of Microbiology, \\ Yunnan University, 650091 Kunming, PR China \\ ${ }^{2}$ College of Resources and Environment, Northwest A \& F University, 712100 Yangling, PR China
}

A straight-chain, spore-forming actinobacterium, strain YIM $120770^{\top}$, was isolated from soil. Phylogenetic analysis on the basis of 16S rRNA gene sequence comparisons revealed that the isolate represents a distinct cluster within the clade comprising the genus Nonomuraea and is related most closely to Nonomuraea rhizophila YIM $67092^{\top}$ (96.5\% similarity). Cells of strain YIM $120770^{\top}$ grew in the presence of $0-3 \%(\mathrm{w} / \mathrm{v}) \mathrm{NaCl}$, at $15-37{ }^{\circ} \mathrm{C}$ and at $\mathrm{pH} 7.0-8.0$. The diagnostic amino acid was meso-diaminopimelic acid, cell hydrolysates contained madurose, glucose, mannose, ribose and galactose, the predominant cellular fatty acids were 10-methyl $\mathrm{C}_{17: 0}$ and iso- $\mathrm{C}_{16: 0}$, and the DNA G $+\mathrm{C}$ content was $66.4 \mathrm{~mol} \%$, data consistent with affiliation of strain YIM $120770^{\top}$ to the genus Nonomuraea. Strain YIM $120770^{\top}$ shared low levels of $16 \mathrm{~S}$ rRNA gene sequence similarity $(<97 \%)$ with the type strains of recognized species of the genus Nonomuraea and could be differentiated from its closest phylogenetic relative based on phenotypic characteristics. These results suggested that strain YIM $120770^{\top}$ represents a novel species of the genus Nonomuraea, for which the name Nonomuraea soli sp. nov. is proposed. The type strain is YIM $120770^{\top}\left(=\mathrm{DSM} 45533^{\top}=\mathrm{JCM} 17347^{\top}\right)$.
The etymology of the genus Nonomuraea was corrected by Chiba et al. (1999) following description of the genus Nonomuria by Zhang et al. (1998). At the time of writing, the genus comprised 26 recognized species and two subspecies (http://www.bacterio.cict.fr/n/nonomuraea.html).

In an attempt to investigate the diversity of actinomycetes from Weibao Mountain in Dali, Yunnan province, China, numerous strains were obtained and characterized taxonomically. Preliminary comparative 16S rRNA gene sequence analysis showed that one of these strains, designated YIM $120770^{\mathrm{T}}$, formed a separate lineage within the genus Nonomuraea. As a consequence, it was subjected to further taxonomic study by using a polyphasic approach, which included determination of its phenotypic properties and detailed phylogenetic analysis based on $16 \mathrm{~S}$ rRNA gene sequences.

A soil sample was collected from an altitude of $2670 \mathrm{~m}$ from Weibao Mountain in south-west China in April 2010. The soil suspension was diluted and spread onto mycoseproline agar [5 $\mathrm{g}$ mycose, $1 \mathrm{~g}$ proline, $1 \mathrm{~g}\left(\mathrm{NH}_{4}\right)_{2} \mathrm{SO}_{4}, 1 \mathrm{~g}$ $\mathrm{NaCl}, 2 \mathrm{~g} \mathrm{CaCl}_{2}, 1 \mathrm{~g} \mathrm{~K}_{2} \mathrm{HPO}_{4}, 1 \mathrm{~g} \mathrm{MgSO}_{4} .7 \mathrm{H}_{2} \mathrm{O}, 3.7 \mathrm{mg}$

The GenBank/EMBL/DDBJ accession number for the 16S rRNA gene sequence of strain YIM $120770^{\top}$ is JF742631.

One supplementary figure is available with the online version of this paper. vitamin mixture (Hayakawa \& Nonomura, 1987), $20 \mathrm{~g}$ agar, pH 7.2] after incubation at $28{ }^{\circ} \mathrm{C}$ for 30 days.

General cell morphology was studied by light microscopy (Olympus BH-2) and scanning electron microscopy (QUANTA200; FEI) of a 21-day-old culture of strain YIM $120770^{\mathrm{T}}$ grown on ISP 2 agar medium (Shirling \& Gottlieb, 1966). For cultural characterization, strain YIM $120770^{\mathrm{T}}$ was grown for 28 days at $28{ }^{\circ} \mathrm{C}$ on ISP media 2, 3, 4 and 5 (Shirling \& Gottlieb, 1966), nutrient agar (Difco), Czapek's agar (Waksman, 1967) and potato-dextrose agar. The colours of substrate and aerial mycelia and any soluble pigments produced were determined by comparison with chips from the colour charts of the Inter-Society Color Council (Kelly, 1964). Temperature and $\mathrm{pH}$ ranges for growth and $\mathrm{NaCl}$ tolerance were determined on ISP medium 2 as described by $\mathrm{Xu}$ et al. (2005). Catalase and oxidase activity was detected by the method of Wang et al. (2008). Hydrolysis of starch, cellulose, gelatin, Tweens 20, 40, 60 and 80, milk coagulation and peptonization, reduction of nitrate, urease activity and $\mathrm{H}_{2} \mathrm{~S}$ production were determined as described by Smibert \& Krieg (1994). Utilization of compounds as sole carbon and nitrogen sources was tested according to Gordon et al. (1974).

Strain YIM $120770^{\mathrm{T}}$ for chemotaxonomic analyses was cultured in ISP 2 broth at $28{ }^{\circ} \mathrm{C}$ for 14 days. Diaminopimelic 
acids and whole-cell sugars were analysed according to the methods described by Hasegawa et al. (1983) and Tang et al. (2009), respiratory quinones were extracted according to Collins et al. (1977) and identified by HPLC (Groth et al., 1996), and analysis of polar lipids was performed by TLC as described by Minnikin et al. (1979) and Collins \& Jones (1980). Biomass for fatty acid analysis was harvested from a Bacto trypticase soy broth shaker after 7 days at $28^{\circ} \mathrm{C}$. Nonomuraea rhizophila YIM $67092^{\mathrm{T}}$ was used in parallel for the above experiments. Cellular fatty acid methyl esters were prepared as described by Sasser (1990) and analysed according to the standard protocol of the Microbial Identification System (Sherlock Version 6.1; MIDI database: TSBA6). GC was performed with an Agilent Technologies 7890A system.

Genomic DNA was extracted and purified, and PCRmediated amplification of the 16S rRNA gene was performed as described by Li et al. (2007). The $16 \mathrm{~S}$ rRNA gene sequence of strain YIM $120770^{\mathrm{T}}$ was aligned with corresponding sequences obtained from the DDBJ/EMBL/ GenBank databases by using the EzTaxon server (http://147. 47.212.35:8080/) (Chun et al., 2007). Multiple alignment of the data was performed by using the program CLUSTAL $\mathrm{X}$ (Thompson et al., 1997). Phylogenetic and molecular evolutionary analyses were conducted with the neighbourjoining (Saitou \& Nei, 1987), maximum-parsimony (Fitch, 1971) and maximum-likelihood (Felsenstein, 1981) methods. A phylogenetic tree was constructed by using the neighbour-joining method of Saitou \& Nei (1987) with MEGA version 4 (Tamura et al., 2007). Evolutionary distance matrices (distance options according to the Kimura twoparameter model) were calculated as described by Kimura (1980). The tree topology was assessed by using bootstrap analysis with 1000 replicated datasets (Felsenstein, 1985). The DNA G + C content of strain YIM $120770^{\mathrm{T}}$ was determined by reversed-phase HPLC of nucleosides according to Mesbah et al. (1989).

The 16S rRNA gene sequence of strain YIM $120770^{\mathrm{T}}$ showed $94.3-96.5 \%$ similarity to those of the type strains of all recognized species of the genus Nonomuraea. Strain YIM $120770^{\mathrm{T}}$ was related most closely to the type strain of N. rhizophila YIM $67092^{\mathrm{T}}$ (96.5\% $16 \mathrm{~S}$ rRNA gene sequence similarity), and phylogenetic analysis based on 16S rRNA gene sequences showed that strain YIM $120770^{\mathrm{T}}$ formed a cluster with the type strains of $N$. rhizophila YIM $67092^{\mathrm{T}}$ and Nonomuraea rosea GW $12687^{\mathrm{T}}$ (96.1\% $16 \mathrm{~S}$ rRNA gene sequence similarity) (Fig. 1), which was supported by a high bootstrap value $(78 \%)$. This cluster did not form any definite clusters with other closely related Nonomuraea strains. 16S rRNA gene sequence analysis thus suggested that strain YIM $120770^{\mathrm{T}}$ represents a novel species of the genus Nonomuraea. The DNA G + C content of strain YIM $120770^{\mathrm{T}}$ was $66.4 \mathrm{~mol} \%$.

With regard to chemotaxonomic characteristics, strain YIM $120770^{\mathrm{T}}$ had meso-diaminopimelic acid as the diagnostic diamino acid in the cell-wall peptidoglycan, and madurose, mannose and galactose as diagnostic sugars. The major menaquinones were MK-9 $\left(\mathrm{H}_{4}\right)(68.8 \%)$, MK- $9\left(\mathrm{H}_{6}\right)(14.9 \%)$ and MK- $9\left(\mathrm{H}_{2}\right)(14.5 \%)$, and the polar lipids comprised diphosphatidylglycerol, phosphatidylmethylethanolamine, phosphatidylethanolamine, OH-phosphatidylethanolamine, $\mathrm{OH}-$ phosphatidylmonomethylethanolamine, phosphatidylglycerol, phosphatidylinositol, phosphatidylinositol mannoside, an unknown aminophosphoglycolipid and three unknown phospholipids (see Fig. S1 in IJSEM Online). The predominant fatty acids were 10 -methyl $\mathrm{C}_{17: 0}(12.8 \%)$, iso- $\mathrm{C}_{16: 0}(11.9 \%)$, $\mathrm{C}_{17: 1} \omega 6 c(9.2 \%)$, anteiso- $\mathrm{C}_{15: 0}(7.4 \%)$ and $\mathrm{C}_{16: 0}(7.4 \%)$. Other components were $\mathrm{C}_{17: 1} \omega 8 c(5.8 \%), 10$-methyl $\mathrm{C}_{16: 0}$ $(5.4 \%)$, iso- $\mathrm{C}_{14: 0}(5.3 \%)$, iso- $\mathrm{C}_{15: 0}(5.0 \%)$, summed feature 3 $\left(\mathrm{C}_{16: 1} \omega 7 c\right.$ and/or $\left.\mathrm{C}_{16: 1} \omega 6 c, 4.6 \%\right), \mathrm{C}_{14: 0}(3.6 \%), \mathrm{C}_{18: 0}$ (2.6\%), iso- $\mathrm{C}_{16: 1} \mathrm{G}(2.5 \%), \mathrm{C}_{16: 0} 2-\mathrm{OH}(2.5 \%), \mathrm{C}_{17: 0}$ $(2.3 \%), \mathrm{C}_{15: 0} 2-\mathrm{OH}(2.2 \%)$, anteiso- $\mathrm{C}_{17: 0}(2.1 \%), \mathrm{C}_{13: 0}$ (1.9\%), 10-methyl $\mathrm{C}_{18: 0}(1.4 \%), \mathrm{C}_{18: 1} \omega 9 \mathrm{c}(1.3 \%)$, iso- $\mathrm{C}_{17: 0}$ $(0.8 \%), \mathrm{C}_{17: 0} 2-\mathrm{OH}(0.6 \%)$, iso- $\mathrm{C}_{18: 0}(0.3 \%)$, anteiso- $\mathrm{C}_{15: 1}$ A (0.2\%), iso- $\mathrm{C}_{15: 1} \mathrm{G}(0.2 \%), \mathrm{C}_{14: 0} 2-\mathrm{OH}(0.2 \%)$, anteiso$\mathrm{C}_{17: 1} \mathrm{~A}(0.2 \%), \mathrm{C}_{12: 0} 3-\mathrm{OH}(0.2 \%)$ and iso- $\mathrm{C}_{13: 0}(0.1 \%)$.

Strain YIM $120770^{\mathrm{T}}$ formed extensively branched substrate mycelia and aerial mycelia on ISP 2 agar, spore chains borne on aerial mycelia were straight and the spore surfaces were smooth (Fig. 2). Good growth was observed on ISP 2 and nutrient media, and moderate growth was seen on other media tested. Orange-yellow to orange substrate mycelia and white aerial mycelia appeared on all media tested. No diffusible pigment was produced on any medium. Other physiological properties are given in the species description below and in Table 1 .

16S rRNA gene sequence analysis (Fig. 1) showed that strain YIM $120770^{\mathrm{T}}$ belongs to the genus Nonomuraea. It formed extensively branched substrate and aerial mycelia and straight chains of spores with a smooth ornamentation. The diagnostic diamino acid, cell hydrolysates, predominant menaquinones, polar lipids (Fig. S1), major fatty acids and DNA G $+\mathrm{C}$ content were all consistent with its classification in the genus Nonomuraea.

However, strain YIM $120770^{\mathrm{T}}$ could be differentiated phenotypically from its closest phylogenetic neighbours, $N$. rhizophila YIM $67092^{\mathrm{T}}$ and N. rosea GW $12687^{\mathrm{T}}$, based on morphology (Fig. 2). In addition, strain YIM $120770^{\mathrm{T}}$ differed from N. rhizophila YIM $67092^{\mathrm{T}}$ and N. rosea GW $12687^{\mathrm{T}}$ in utilization of cellobiose, D-fructose, myo-inositol, lactose, hypoxanthine and xanthine. In the polar lipid profile, strain YIM $120770^{\mathrm{T}}$ contained $\mathrm{OH}$-phosphatidylmonomethylethanolamine, $\mathrm{OH}$-phosphatidylethanolamine and an unknown aminophosphoglycolipid, which were lacking in N. rhizophila YIM $67092^{\mathrm{T}}$ and $N$. rosea GW $12687^{\mathrm{T}}$. Strain YIM $120770^{\mathrm{T}}$ also differed from $N$. rhizophila YIM $67092^{\mathrm{T}}$ and N. rosea GW $12687^{\mathrm{T}}$ in lacking iso- $\mathrm{C}_{16: 1} \mathrm{G}$ as a major fatty acid $(\geqslant 5.0 \%)$. Strain YIM $120770^{\mathrm{T}}$ lacked MK-9, which accounts for $6 \%$ in strain $N$. rosea $\mathrm{GW} 12687^{\mathrm{T}}$. Differential characteristics among strain YIM $120770^{\mathrm{T}}$, N. rhizophila YIM $67092^{\mathrm{T}}$ and N. rosea GW $12687^{\mathrm{T}}$ are given in Table 1. 


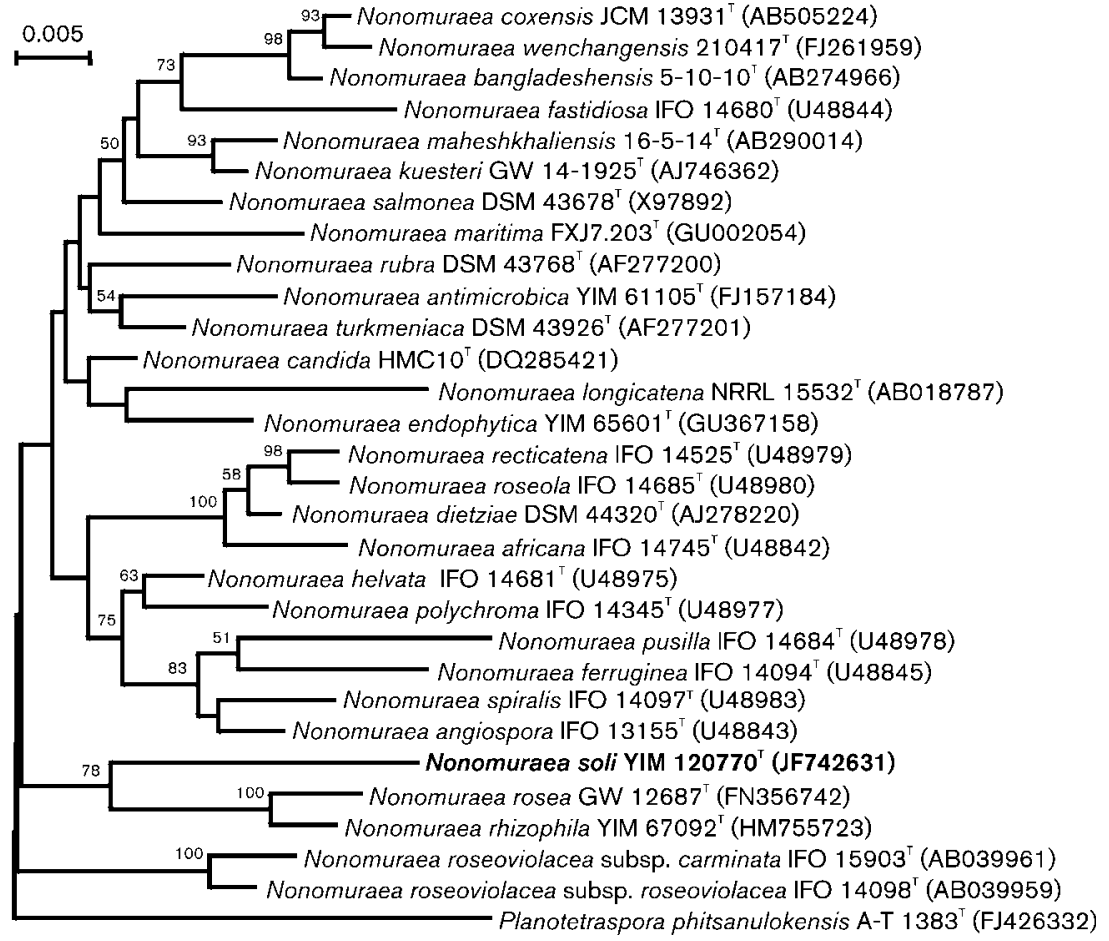

Fig. 1. Neighbour-joining phylogenetic tree based on nearly complete 16S rRNA gene sequences (1524 nt) showing the relationship between strain YIM $120770^{\top}$ and members of the genus Nonomuraea. Numbers at branch nodes are bootstrap values based on 1000 resamplings; only values $\geqslant 50 \%$ are shown. The sequence of Planotetraspora phitsanulokensis A-T $1383^{\top}$ was used as an outgroup. Bar, 0.005 substitutions per nucleotide position.
On the basis of data from the present taxonomic study, we conclude that strain YIM $120770^{\mathrm{T}}$ represents a novel species of the genus Nonomuraea, for which the name Nonomuraea soli sp. nov. is proposed.

\section{Description of Nonomuraea soli sp. nov.}

Nonomuraea soli (so'li. L. neut. gen. n. soli of soil, the source of the type strain).

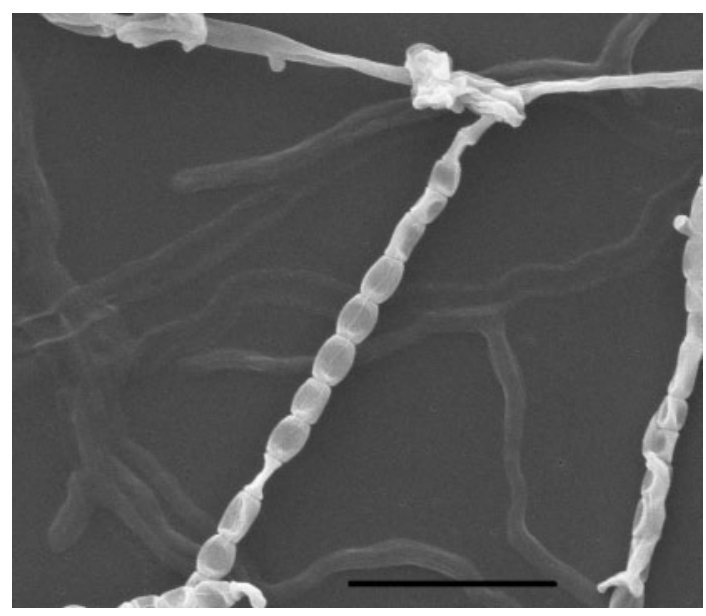

Fig. 2. Scanning electron micrograph of spiral spore chains on aerial mycelium of strain YIM $120770^{\top}$ grown on ISP 2 at $28^{\circ} \mathrm{C}$ for 21 days. Bar, $5 \mu \mathrm{m}$.
Substrate mycelia are orange-yellow to orange and aerial mycelia are white. Spore chains are straight, and show a smooth ornamentation. No diffusible pigment is produced. Growth occurs at $15-37{ }^{\circ} \mathrm{C}$ (optimum $28{ }^{\circ} \mathrm{C}$ ), at pH 7.0-8.0 (optimum $\mathrm{pH} 7.0$ ) and in the presence of $0-3 \% \mathrm{NaCl}$ (optimum $0 \%$ ). Positive for catalase, oxidase and nitrate reductase; negative for hydrolysis of starch, cellulose, gelatin, and Tweens 20, 40, 60 and 80, milk coagulation and peptonization, urease activity and $\mathrm{H}_{2} \mathrm{~S}$ production. Utilizes glucose, maltose, D-mannose, D-mannitol, raffinose, Lrhamnose, glycerol, D-sorbitol, D-xylose, xylitol, succinic acid and sodium DL-malate, but not cellobiose, D-fructose, myo-inositol, lactose, L-arabinose, D-galactose, dextrin, dulcitol, fucose or L-sorbose. Utilizes L-serine and adenine as sole nitrogen sources, but not hypoxanthine or xanthine. The diagnostic diamino acid is meso-diaminopimelic acid. Cell hydrolysates contain madurose, ribose, mannose, glucose and galactose. The predominant menaquinones are MK-9 $\left(\mathrm{H}_{4}\right)$, MK-9 $\left(\mathrm{H}_{6}\right)$ and MK-9 $\left(\mathrm{H}_{2}\right)$. Polar lipids include diphosphatidylglycerol, phosphatidylmethylethanolamine, phosphatidylethanolamine, $\mathrm{OH}$-phosphatidylethanolamine, $\mathrm{OH}$-phosphatidylmonomethylethanolamine, phosphatidylglycerol, phosphatidylinositol, phosphatidylinositol mannoside, an unknown aminophosphoglycolipid and three unknown phospholipids. Major fatty acids are 10-methyl $\mathrm{C}_{17: 0}$, iso- $\mathrm{C}_{16: 0}, \mathrm{C}_{17: 1} \omega 6 c$, anteiso- $\mathrm{C}_{15: 0}$ and $\mathrm{C}_{16: 0}$.

The type strain, YIM $120770^{\mathrm{T}}\left(=\mathrm{DSM} \quad 45533^{\mathrm{T}}=\mathrm{JCM}\right.$ $17347^{\mathrm{T}}$ ), was isolated from Weibao Mountain, south-west China. The DNA $\mathrm{G}+\mathrm{C}$ content of the type strain is $66.4 \mathrm{~mol} \%$. 
Table 1. Characteristics that differentiate strain $\mathrm{YIM} 120770^{\top}$ from the type strains of Nonomuraea rhizophila and Nonomuraea rosea Strains: 1, YIM $120770^{\mathrm{T}} ; 2$, N. rhizophila YIM $67092^{\mathrm{T}} ; 3$, N. rosea GW $12687^{\mathrm{T}}$. Data are from the present study except where indicated. ND, Not determined.

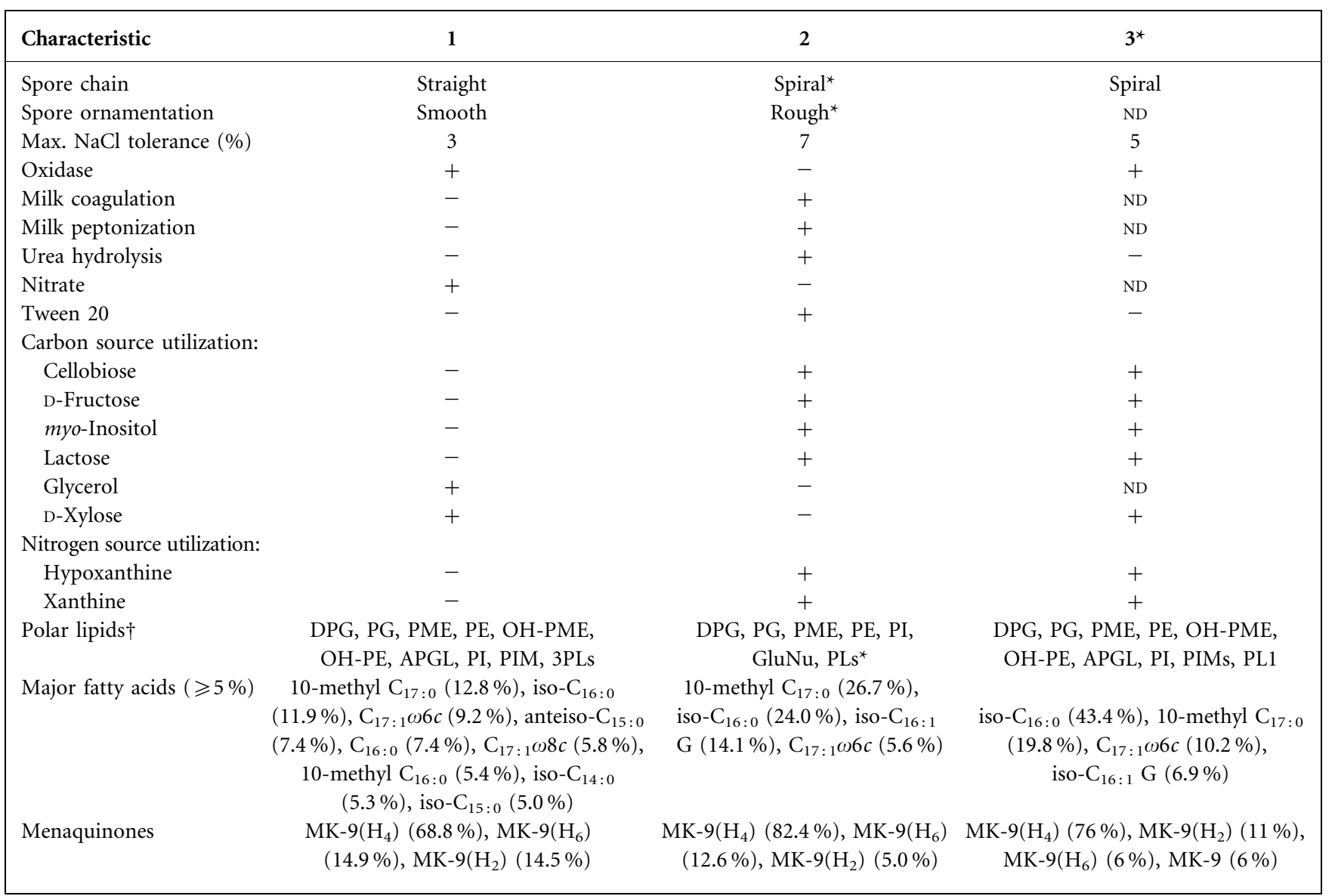

${ }^{\star}$ Data from Zhao et al. (2011) and Kämpfer et al. (2010).

$\nmid$ DPG, Diphosphatidylglycerol; PG, phosphatidylglycerol; PL, phospholipid; PME, phosphatidylmethylethanolamine; PE, phosphatidylethanolamine; OHPME, OH-phosphatidylmonomethylethanolamine; OH-PE, OH-phosphatidylethanolamine; APGL, unknown aminophosphoglycolipid; PI, phosphatidylinositol; PIM, phosphatidylinositol mannoside; GluNu, unknown glucosamine-containing phospholipid.

\section{Acknowledgements}

This research was supported by the National Natural Science Foundation of China (no. 30900002 and no. 21062028), National Major Scientific and Technology Special Projects (2009ZX09302-003) and National Institutes of Health (1P41GM086184-01A1).

\section{References}

Chiba, S., Suzuki, M. \& Ando, K. (1999). Taxonomic re-evaluation of 'Nocardiopsis' sp. K- $252^{\mathrm{T}}$ (= NRRL $\left.15532^{\mathrm{T}}\right)$ : a proposal to transfer this strain to the genus Nonomuraea as Nonomuraea longicatena sp. nov. Int J Syst Bacteriol 49, 1623-1630.

Chun, J., Lee, J. H., Jung, Y., Kim, M., Kim, S., Kim, B. K. \& Lim, Y. W. (2007). EzTaxon: a web-based tool for the identification of prokaryotes based on $16 \mathrm{~S}$ ribosomal RNA gene sequences. Int J Syst Evol Microbiol 57, 2259-2261.

Collins, M. D. \& Jones, D. (1980). Lipids in the classification and identification of coryneform bacteria containing peptidoglycan based on 2, 4-diaminobutyric acid. J Appl Bacteriol 48, 459-470.
Collins, M. D., Pirouz, T., Goodfellow, M. \& Minnikin, D. E. (1977). Distribution of menaquinones in actinomycetes and corynebacteria. $J$ Gen Microbiol 100, 221-230.

Felsenstein, J. (1981). Evolutionary trees from DNA sequences: a maximum likelihood approach. J Mol Evol 17, 368-376.

Felsenstein, J. (1985). Confidence limits on phylogenies: an approach using the bootstrap. Evolution 39, 783-789.

Fitch, W. M. (1971). Toward defining the course of evolution: minimum change for a specific tree topology. Syst Zool 20, 406416.

Gordon, R. E., Barnett, D. A., Handerhan, J. E. \& Pang, C. H.-N. (1974). Nocardia coeliaca, Nocardia autotrophica, and the nocardin strain. Int J Syst Bacteriol 24, 54-63.

Groth, I., Schumann, P., Weiss, N., Martin, K. \& Rainey, F. A. (1996). Agrococcus jenensis gen. nov., sp. nov., a new genus of actinomycetes with diaminobutyric acid in the cell wall. Int J Syst Bacteriol 46, 234239.

Hasegawa, T., Takizawa, M. \& Tanida, S. (1983). A rapid analysis for chemical grouping of aerobic actinomycetes. J Gen Appl Microbiol 29, 319-322. 
Hayakawa, M. \& Nonomura, H. (1987). Humic acid-vitamin agar, a new medium for the selective isolation of soil actinomycetes. J Ferm Technol 65, 501-509.

Kämpfer, P., Busse, H. J., Tindall, B. J., Nimtz, M. \& Grün-Wollny, I. (2010). Nonomuraea rosea sp. nov. Int J Syst Evol Microbiol 60, 11181124.

Kelly, K. L. (1964). Inter-Society Color Council-National Bureau of Standards Color Name Charts Illustrated with Centroid Colors. Washington, DC: US Government Printing Office.

Kimura, M. (1980). A simple method for estimating evolutionary rates of base substitutions through comparative studies of nucleotide sequences. J Mol Evol 16, 111-120.

Li, W. J., Xu, P., Schumann, P., Zhang, Y. Q., Pukall, R., Xu, L. H., Stackebrandt, E. \& Jiang, C. L. (2007). Georgenia ruanii sp. nov., a novel actinobacterium isolated from forest soil in Yunnan (China), and emended description of the genus Georgenia. Int J Syst Evol Microbiol 57, 1424-1428.

Mesbah, M., Premachandran, U. \& Whitman, W. B. (1989). Precise measurement of the $\mathrm{G}+\mathrm{C}$ content of deoxyribonucleic acid by highperformance liquid chromatography. Int J Syst Bacteriol 39, 159-167.

Minnikin, D. E., Collins, M. D. \& Goodfellow, M. (1979). Fatty acid and polar lipid composition in the classification of Cellulomonas, Oerskovia and related taxa. J Appl Bacteriol 47, 87-95.

Saitou, N. \& Nei, M. (1987). The neighbor-joining method: a new method for reconstructing phylogenetic trees. Mol Biol Evol 4, 406-425.

Sasser, M. (1990). Identification of bacteria by gas chromatography of cellular fatty acids, Technical Note 101. Newark, DE: MIDI Inc.

Shirling, E. B. \& Gottlieb, D. (1966). Methods for characterization of Streptomyces species. Int J Syst Bacteriol 16, 313-340.
Smibert, R. M. \& Krieg, N. R. (1994). Phenotypic characterization. In Methods for General and Molecular Bacteriology, pp. 607-654. Edited by P. Gerhardt, R. G. E. Murray, W. A. Wood \& N. R. Krieg. Washington, DC: American Society for Microbiology.

Tamura, K., Dudley, J., Nei, M. \& Kumar, S. (2007). MEGA4: molecular evolutionary genetics analysis (MEGA) software version 4.0. Mol Biol Evol 24, 1596-1599.

Tang, S. K., Wang, Y., Chen, Y., Lou, K., Cao, L. L., Xu, L. H. \& Li, W. J. (2009). Zhihengliuella alba sp. nov., and emended description of the genus Zhihengliuella. Int J Syst Evol Microbiol 59, 2025-2032.

Thompson, J. D., Gibson, T. J., Plewniak, F., Jeanmougin, F. \& Higgins, D. G. (1997). The CLUSTAL_X windows interface: flexible strategies for multiple sequence alignment aided by quality analysis tools. Nucleic Acids Res 25, 4876-4882.

Waksman, S. A. (1967). The Actinomycetes. A Summary of Current Knowledge. New York: Ronald Press.

Wang, Y. X., Zhang, Y. Q., Xu, L. H. \& Li, W. J. (2008). Actinopolymorpha rutila sp. nov., isolated from a forest soil. Int $J$ Syst Evol Microbiol 58, 2443-2446.

Xu, P., Li, W. J., Tang, S. K., Zhang, Y. Q., Chen, G. Z., Chen, H. H., Xu, L. H. \& Jiang, C. L. (2005). Naxibacter alkalitolerans gen. nov., sp. nov., a novel member of the family 'Oxalobacteraceae' isolated from China. Int J Syst Evol Microbiol 55, 1149-1153.

Zhang, Z. S., Wang, Y. \& Ruan, J. S. (1998). Reclassification of Thermomonospora and Microtetraspora. Int J Syst Bacteriol 48, 411422.

Zhao, G.-Z., Li, J., Huang, H.-Y., Zhu, W.-Y., Xu, L.-H. \& Li, W.-J. (2011). Nonomuraea rhizophila sp. nov., an actinomycete isolated from rhizosphere soil. Int J Syst Evol Microbiol 61, 2141-2145. 